\title{
The importance of human capital in contemporary small and medium-sized companies in the opinion of managers: Pilot research in Podkarpackie Voivodeship in Poland
}

\section{AgNIESZKa RZEPKA ${ }^{1}$}

Lublin University of Technology, Department of Economics and Economic Management

\author{
BOGUSŁAW ŚLUSARCZYK ${ }^{2}$ \\ University of Rzeszów, Department of Macroeconomics and International Relations
}

\begin{abstract}
In world economy, which develops dynamically the meaning of human capital which has a significant influence on building competitive advantages in contemporary enterprises of all countries becomes more and more important. The intention of the authors of this article was to specify the role of human capital in obtaining competitive advantages by small and medium-sized companies of the Podkarpackie region in Poland in the opinion of managers.

To achieve this objective, a survey was conducted among 300 enterprises from the trade, service, construction and production industries. The managers of these enterprises, emphasized in answers they provided, that building a permanent competitive advantage is definitely dependent on the quality of human resources and their use during the course of business activity regardless of its nature.
\end{abstract}

Paper type: research article

Keywords: human capital, relationships, competitive advantage, SME, Podkarpackie voivodeship

\footnotetext{
a.rzepka@pollub.pl

2 boguslaw.slusarczyk@gmail.com
} 


\section{Introduction}

In business and in a dynamic environment, gaining competitive advantage requires having specific resources which distinguish the company from its competition. These resources should be characterized by their uniqueness, should be difficult to reproduce or imitate and should be flexible enough to allow for a quick response to any changes in the environment. Such resources should ensure that a lasting competitive advantage can be created. Human capital is undoubtedly the main source of competitive advantage. This can be explained by the fact that the remaining assets of the company can be measured more easily and therefore can be standardized. Moreover, they are fully comparable. Human capital is presently seen as the most essential among the strategic resources of any company. It is the people who determine the company's advantage over its competition. The transition of the world economy from an industry and commerce-based one to an information and service economy (labelled by many as a "knowledge-based" economy, which means that the importance of human capital in contemporary companies is significant and continues to grow) results in a devaluation of the traditional resource-based approach to one based on strategic thinking.

The importance of human capital has been recognized by theorists and in business practice in recent years. Currently, human capital should serve as a foundation for the management and the development of the company's strategy which must be designed to increase the company's position in the market. It is the company's responsibility to acquire and develop appropriate human capital. Skilful use of human resources will allow companies to develop a sustainable competitive advantage in the market.

The objective of the article was to specify the role of human capital in obtaining competitive advantages by small and medium-sized companies of the Podkarpackie region in Poland. Accomplishment of the goal requires conducting quantitative research and use a questionnaire method of research.

\section{The definition of human capital}

Both in theory and in practice, it is very difficult to find a uniform definition of human capital. Human capital is a term which is heavily "loaded" theoretically and empirically. The term is associated with a wide range of keywords, which impedes its operationalization. Dozens of different definitions of the term are found in the literature. Table 1 presents various definitions of the phrase suggested by the Polish and foreign authors.

Human capital consists of competence, skills, experience and applied approaches in management practice. If it is considered in relation to a particular employee, 
Table 1 Various definitions of human capital supplied by Polish and foreign authors

\begin{tabular}{|l|l|}
\hline Author & \multicolumn{1}{|c|}{ Human capital definition } \\
\hline Baron \& Armstrong & $\begin{array}{l}\text { Knowledge, skills, abilities and potential for growth and implementation of } \\
\text { innovations possessed by the employees of a company. }\end{array}$ \\
\hline Bontis & $\begin{array}{l}\text { The human factor of the company, which combines intelligence, skills and } \\
\text { expertise - all of which give the company its distinctive character. }\end{array}$ \\
\hline Ulrich & Competence multiplied by commitment. \\
\hline Kożuch & $\begin{array}{l}\text { The stock of knowledge and skills acquired through education and work expe- } \\
\text { rience, but also human resources of health and vitality. }\end{array}$ \\
\hline Sajkiewicz & $\begin{array}{l}\text { The people permanently associated with the company and its mission, who } \\
\text { display such features as the ability to collaborate, creative attitude and qualifi- } \\
\text { cations. They are the driving force and the heart of the company, and without } \\
\text { whom the company's further development would be impossible. }\end{array}$ \\
\hline Grodzicki & $\begin{array}{l}\text { Knowledge, skills and abilities possessed by individuals, that are of economic } \\
\text { value to the company. }\end{array}$ \\
\hline Pocztowski & $\begin{array}{l}\text { The entirety of unique attributes and properties embodied in employees which } \\
\text { have a certain value and are a source of future income for both the owner of } \\
\text { human capital and for the company benefiting from it. }\end{array}$ \\
\hline Rybak & $\begin{array}{l}\text { People who can collaborate - people permanently associated with the com- } \\
\text { pany and its mission. }\end{array}$ \\
\hline Gableta & $\begin{array}{l}\text { It is inseparably connected with the physical mental, intellectual as well as } \\
\text { moral characteristics of individuals. }\end{array}$ \\
\hline
\end{tabular}

Source: Król \& Ludwiczyński, 2006, p. 11.

it is often called individual capital and defined as "individual, personal and social skills, experience, education and other abilities oriented outwards, towards the company's customers" (Sveiby, 1998, p. 59).

One can conclude that human capital is indispensably linked to a human being, and it includes knowledge, skills, experience and competence of employees. Human capital is defined as the ability of an employee to perform tasks, solve problems emerging in the company, but it is also the ability to create relationships which are based on understanding and trust. Human capital serves as a vehicle for generating knowledge in the company. The basic feature of human capital is that it is not owned by the company, and is only used by the company at the time of a person's employment. Should the employee leave the company, loss of certain skills and abilities occurs in the company (Beyer, 2010, p.175).

Many authors (i.e. Rutka, Czerska, \& Kunc, 2009; Fitz-Enz, 2000) draw attention to the fact that human capital could be developed through investments in people, investments in the advancement of knowledge and skills, and investments in maintaining and improving the employee's health and vitality (Piotrowski, 2009, p. 5). It is the human capital - the carrier of which is a competent employee that enables the company to achieve the added value contained in new products or methods of improving productivity growth. One of the characteristic features of human capital is the possibility of a spontaneous increase in the value of the people 
thanks to continuous learning or gaining experience. This is the only kind of capital that can add value to itself and by itself (Fitz-Enz, 2000, p. 9).

Fitz-Enz (2001) points to the fact that resources such as cash, credit, materials, machines do not add to their own value until a human being increases their value through their appropriate application/use. The theory behind human capital clearly emphasizes the importance of the added value brought to company by its employees. It presents people as valuable assets, and stresses the fact that any investments in staff made by the management of the company allow them to get a satisfactory return on the investments. Considering the company's employees as its assets, the application of the theory of human capital is of great importance in management practice (Fitz-Enz, 2001, p. 12).

\section{The impact of human capital on building competitive advantage}

The problem of building competitive advantage has recently gained crucial importance, especially in the context of the need for development in a rapidly changing environment. Competitive advantage is a critical factor for success in the market which helps to increase the company's profitability, to act globally and to "reach out to the future before the others do." In the process of building competitive advantage, companies can make use of a variety of factors and their combinations (Nogalski \& Rybicki, 2007, pp. 33-44).

In current economy, it is the human capital that is more and more frequently given an increasing significance in building strategic advantage and competitiveness of modern companies. It is an important intangible source of development of enterprises, but at the same time is not subject to their ownership.

In the context of the human capital theory, it is believed that humans are genetically endowed with a particular set of characteristics and properties. These properties may or may not be developed. As a result, there is a natural need to invest in their development. Treating employees as an object of investment includes them in the area of economic analysis in relation not only to the costs generated in the company, but also in the context of increasing the value of the human capital with a view to its future use (Olesiuk, 2009, p. 47).

Investing in a person who embodies specific human capital remains the primary responsibility of any company that wishes to have products or services at more than just an average level. Human capital, effectively enlarged and amplified, can become the key factor of economic growth, and contribute to the creation of new values, products, technologies or organizational systems.

It appears that the dominant approach to understanding human capital is one where the company's intangible assets are equated with its intellectual capi- 
tal. It consists of three groups of assets (Mikuła, Pietruszka-Ortyl, \& Potocki, 2002, pp. 37-39): ${ }^{3}$ the employees' competence, the company's internal structure and its system of external relations. Therefore, the company's intellectual capital tends to be understood as a sum of such elements as human capital, organizational capital, market capital, innovation capital, or human, social and organizational capital (Jabłoński, 2002, pp. 14-16; Pocztowski, 2003, p. 6). In this sense, human capital is seen as the foundation for the existence, creation and operation of the other elements of intellectual capital, all of which are considered "soft" components of the entity's resources and secondary to human resources.

It should be noted, that intellectual capital is always based on human capital. Sharing knowledge and its distribution are extreme importance (Rutka et al., 2009). By mentioning all the components of intellectual capital, however, one can aim to emphasise that although it is the people (human capital) who create the knowledge, it is only through their interactions (social capital) that the scope of this knowledge is increased. The result of this is the creation of institutionalised knowledge belonging to the company (organizational capital). Eventually, it becomes a quasi-public asset (databases, standards, customs, patterns). This particular asset is recognized in the company as a standard feature whose dissemination among the company's employees allows them to improve both their individual performance and the one of the company. By increasing the importance of intangible assets, including human capital, small businesses are able to achieve success thanks to the creativity of their employees. This takes place thanks to the inclusion of the entity in the structure of the business network where it receives financial and organizational support by offering its unique expertise in return (Rosińska, 2007).

In this way, the knowledge of individuals (people scattered in different organizations) is captured by the human resources management systems (the process of recruitment, selection and screening of employees, the system of motivating personnel and supporting their development). In order to expand the knowledge and increase its value, it is important to take full advantage of social and organizational capital, which means of both the accumulated and codified knowledge found in the company and the knowledge that flows through it. The sources of this knowledge are networks of relationships inside and outside the company. Therefore, the result of the implementation of the concept of knowledge-based economy is a gradual development of business links structure (as a result of globalization and liberalization, also of global links structure). What occurs inside this structure is a rapid flow of knowledge and information, and its processing and enrichment. All the entities that participate in the network form an organization. Its strategic goal is development through identifying its unique value-added which allows it to maintain competitive advantage of the organization as a whole. In a modern business enter-

3 There were many attempts to classify non-material resources: enumerate their types, characteristic features in such a way as to indicate their different nature from material assets. 
prise, its employees should be treated as the most valuable assets, and the company should take care of their continuous development. It should be noted that the remaining assets depreciate over time whereas the people have the ability to quickly increase their value through the process of learning. They can also contribute to the creation of added value to a much greater extent than other resources. Thus, in the knowledge-based economy, human resources are seen as a foundation for improving competitiveness and boosting innovation.

One can conclude that investments related to the development of human resources are the most advantageous form of investing capital. In business entities this refers to the improvement of employees' professional skills, but also to the organization of the so-called general development training courses which aim to stimulate the creativity of employees and to motivate them to take on new challenges.

\section{The role of human capital in the relationships between companies}

Not only do properly shaped inter-organizational relationships provide access to valuable resources in the form of human capital, but are also conducive to creating, connecting and sharing of resources, and obtaining values for those involved in the relationship. According to some managers, "as long as the value is being created, everything in the relationship remains good" (Ritter \& Walter, 2008, p. 139).

Undoubtedly, the success of any modern enterprise largely depends on how the relationships with the others are handled (Skalik, 2006, p. 45). Hence, enormous importance is placed on the role and activity of the management, employees and teams willing to cooperate with outside entities. Great significance for the development of the company is given to human capital which uses its own competence, intellectual ability, motivation, and abilities to perform certain organizational roles, including the development of inter-organizational relationships. Relationships with customers, suppliers, competitors and other stakeholders are built via the company's employees. It should be borne in mind that the structural capital is formed through, among others, elements, human capital. It includes new products, patents, licenses, software, technologies and relational capital (i.e. reputation, customer loyalty, strong relationships with stakeholders) (Danielak, 2012, pp. 1-5).

Ability and competence, especially relational competencies associated with the use of knowledge, skills, abilities and attitudes in the area of cooperation, are particularly important in the evolution of the relationships. The creation of relational capital is supported by direct and personal contacts (links) of the employees and executives with the stakeholders which are based on the ability to cooperate, on the ability to trust others and also on one's own credibility and one's core competencies (Grudzewski, Hejduk, Sankowska, \& Wańtuchowicz, 2009, p. 75). 
It is created on the basis of relational resources which are formed between the company and external stakeholders. It results from the formation of appropriate relations with customers, distributors, suppliers and other entities the company deals with (Chomiak-Orsa, 2013, p. 109).

Relational capital could determine the efficacy of the company's affairs and its market success, both from a static perspective - seen as a resource associated with interpersonal relations, as well as from a dynamic perspective - seen as the ability to create and maintain close and lasting relationships based on trust and cooperation.

Relational capital is created on the basis of inter-organizational relationships involving employees as well as the management. It cannot function as a separate phenomenon, but it exists only in relation with human and structural capital, both of which create intellectual capital. As opposed to structural capital which remains the property of the company, relational capital is described as difficult to manage and control. This stems mostly from the specific character of this kind of capital which takes an intangible form that is hard to describe, quantify and measure (Urbanowska-Sojkin, Banaszyk, \& Witczak, 2007, p. 355). The relations are unique and unrepeatable to the cooperating entities. This is due to the specific arrangements between the parties. Hence, a possible acquisition or replication of such relations by other competitive entities may lead to a number of hindrances.

As a result of the formation of strong bonds between the entities involved in the relationship, there is a flow of knowledge and information. And this, in turn, results in the creation of a new range of products or innovations that promote the formation of values.

Dynamic changes in the environment help to strengthen the relations between the parties as they lead to greater flexibility of the organization's activities in the field of solving problem and decision making through involving their own and other entities' competences. The transfer of knowledge is carried out through the means of human and relational capital, whereas the acquisition, maintenance and the renewal of resources necessary to create structural capital is carried out through the means of relationships.

Those involved in the relations must identify variables prior to, during and at the end of the relations. These variables tend to be found in the areas of benefits and costs resulting from the cooperation. Such values as trust and honesty, respect, openness, clear rules of communication play an important role in the formation of inter-organizational relations in the area of human capital. Moreover, the evolution of the criteria for the evaluation of values shows that the non-material criteria are becoming increasingly important, which stems from a growing complexity of economic relations. Therefore, the evaluation of values is burdened with a constantly growing level of subjectivity and uncertainty (Mączyńska, 2011, p. 118). 


\section{Pilot research methodology}

Between September 2015 and March 2016 the authors of this paper conducted a pilot study on the role, size and importance of human capital. The aim of the pilot survey was to identify the role of human capital, its definition and implications from the perspective of individuals holding managerial positions in small and medium-sized companies in the region of Podkarpackie in Poland.

The study included more than 300 respondents randomly selected from the SME sector in the Podkarpackie province. Among the randomly chosen group of enterprises from among many industries a questionnaire was sent by e-mail providing anonymity. It consisted of 25 questions, mainly of a closed type both of a onetype and a multiple choice.

The scope of commercial activities of businesses operating in this geographic included trading, services, real estate, healthcare and social assistance, and construction. As for the size of these companies, the vast majority of them were small and medium-sized enterprises.

In the research, people who represent small enterprises that employ up to $45 \mathrm{em}$ ployees, and medium-sized enterprises (50-249 employees), from various industries and sectors operating in Podkarpackie Voivodeship participated. Micro enterprises were excluded from the research because of the fact that a small number of enterprises gives small possibilities with regard to the human capital management.

Among people who took part in the research, that are people authorized to fill the survey in, the most numerous group consisted of women. There were 164 of them $(54.5 \%)$, whereas the second most numerous group included men $(136,45.5 \%)$. When it comes to the type of activity, the biggest number of the companies were engaged in trading (44.9\%), followed by companies operating in the service sector $(34.6 \%)$, construction $(12.8 \%)$ and production of goods $(7.7 \%)$. No other types of business activities were found.

Considering the scope of business activity, it must be stated that the most extensive group of enterprises included companies that operated only on a local market. Their share amounted to $33 \%$ of a general number of surveyed enterprises. Next group included companies that conducted business activity on a national scale, and their interest comprised $22 \%$ of the total number of enterprises. The least numerous group included internationally operating organizations (16\%).

If we take into account the criterion which is the period of functioning of particular enterprises on the market, the dominant group consisted of companies which period of operation ranged from 8 to 12 years and percentage amounted to $35.9 \%$. Next group consisted of companies that functioned on the market from 3 to 7 years (29.5\%), whereas $24.4 \%$ of surveyed enterprises declared that they had been operating on the market for more than 12 years. The smallest group of companies, $10.2 \%$ of their total number, by contrast, included such which are functioning for a period of time not longer than two years. 


\section{The importance of human capital in the light of pilot research}

Respondents were asked to formulate their definition of human capital. Respondents could choose of the five possible answers provided. Table 2 illustrates the answers given by respondents.

Table 2 Definitions of human capital according to respondents

\begin{tabular}{|l|c|c|}
\hline Human capital & Number of answers & Percentage of answers \\
\hline Skills and competencies of employees & 139 & 46.30 \\
\hline Expertise, experience, health and vitality & 63 & 21.00 \\
\hline Knowledge, education and experience of employees & 70 & 23.35 \\
\hline Adaptability and production potential & 28 & 9.35 \\
\hline Other & 0 & 0.00 \\
\hline Total & 300 & 100.00 \\
\hline
\end{tabular}

The most frequently chosen answer was the one which defined human capital as skills and competencies of employees. Almost half of the respondents (46.30\%) chose this option. $23.35 \%$ of the respondents opted for a definition which saw human capital as knowledge, education and experience of the employees. The next most frequent answer was the one which defined human capital as expertise, experience, health and vitality. None of the respondents attempted to provide their own definition of the term. The distribution of responses shows clearly that human capital is understood by the respondents as a set of employee skills rather than a source of income which the employee embodies.

We asked respondents which type of capital is more important in the company (Figure 1). A total of three possible answers were provided. The most frequent answer was the option that the employees' skills, knowledge and experience were the most important component of the company. This answer was chosen by more than $67.50 \%$ of the respondents. In contrast, $32.5 \%$ of the respondents believe that the financial and material capitals were the most important ones in the company.

The results indicate that the staff and their skills, knowledge and experience are seen as one of the most important elements in the company, however, the financial and material capitals without which any cooperation between people would be impossible.

The study concerned also on the role of human capital in the functioning of the company. The respondents were asked to choose an answer that describes the best their own opinions. Respondents could choose one of the four possible answers (Table 3). 


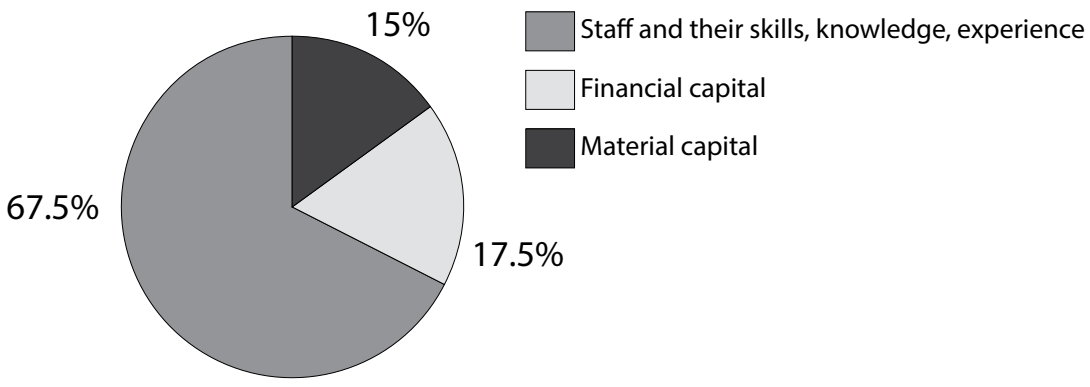

Figure 1. The importance of different types of capital in the company according to respondents.

Table 3 The role of human capital in the functioning of the company according to respondents

\begin{tabular}{|l|c|c|}
\hline Specification & Number of answers & Percentage of answers \\
\hline $\begin{array}{l}\text { Significant role play people and their ideas and this } \\
\text { factor influence the competitive advantage of an } \\
\text { enterprise on the market }\end{array}$ & 188 & 62.66 \\
\hline $\begin{array}{l}\text { Human capital is not the main factor in the decision- } \\
\text { making process and that it is not the most important } \\
\text { element }\end{array}$ & 77 & 25.66 \\
\hline $\begin{array}{l}\text { Human capital is not important for the company as } \\
\text { much as new technologies and machines }\end{array}$ & 35 & 11.63 \\
\hline Human capital fulfils a different function & 0 & 0.00 \\
\hline Total & 300 & 100.00 \\
\hline
\end{tabular}

A significant majority of the respondents (62.66\%) perceived the role of human capital in the same way. Respondents point that people and their ideas played a significant role in the functioning of the company and contribute to the achievement of the competitive advantage of an enterprise on the market. Almost $26 \%$ of the respondents believed that human capital is not the main factor in the decision-making process and that it is not the most important element, whereas only $11.63 \%$ of the respondents said that it was not important for the company as much as new technologies and machines. None of the respondents opted for other possible answers.

The next question was related to the significance of human capital in small and medium-sized companies in the opinion of respondents (Figure 2).

The respondents could choose one of the following four possible answers: yes, rather yes, rather no, or no. A vast majority of the respondents (56\%) chose the yes answer, which means that they thought that in their company human resources occupied an important position. As many as $37 \%$ of the respondents chose rather 


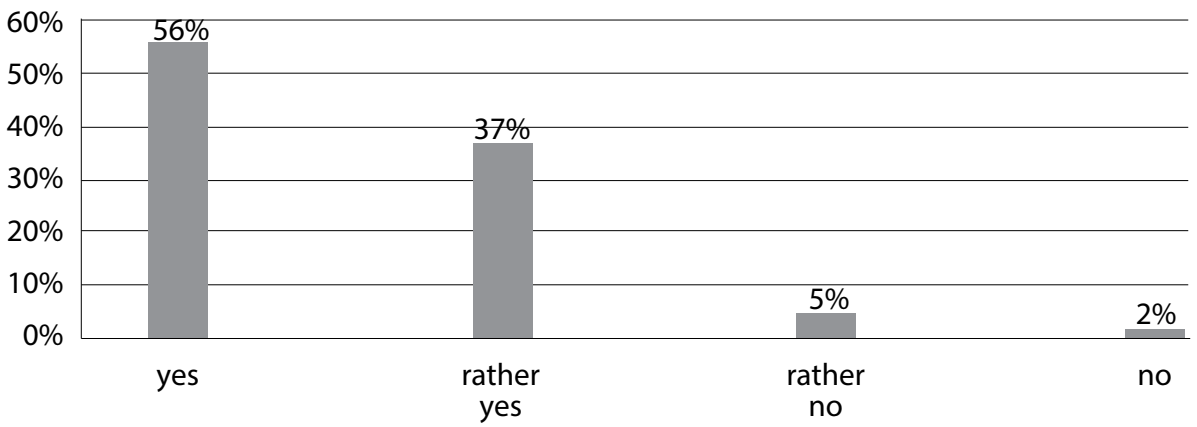

Figure 2. Human capital and its significance in the company according to respondents.

yes, whereas only a few percent of the respondents believed the significance of human capital to be of smaller importance. Clearly, most of the respondents believed that human resources play an important role in the company, which means that the companies they worked for placed great significance on people.

\section{Conclusions}

The results of the survey confirmed, according to responders, that contemporary knowledge, qualifications and investing in human capital are the primary source of competitive advantage. Proper management of the most valuable capital as well as its formation and accumulation can bring many benefits and become the driving force for the functioning and development of companies regardless of their size, but also become a determining factor of their position. What justly emphasises the role of human capital is the following quote by Henry Ford - founder of the Ford Motors Company: "Take everything, but leave me my people, and in two years I'll be at the top again" (Ford, 2006, p. 22).

On the basis of the research carried out among 300 enterprises operating on the territory of Podkarpackie Voivodeship it must be stated that there is no obvious diversification in terms of their type, however, human capital leads to long lasting competitive advantage of a particular enterprise. Moreover, the research shows that investments connected with the development of human resources remain the most beneficial capital venture. It concerns the improvement of professional skills of employees by all-development practice that stimulates creativity of employees and inspires them to undertake challenges.

In economic practice, in a dynamic environment, reaching competitive advantage requires specific resources, which distinguish an enterprise from among competition. These resources should be characterised by uniqueness, difficulty to repli- 
cate and flexibility that would allow for a fast reaction to changes in environment. These resources should provide creating a lasting competitive advantage. Human capital is endowed with above mentioned features the meaning of which had been recently recognized both by theoreticians and by economic practice. Today, in enterprises, human capital should constitute the basis for management as well as for creating a strategy the purpose of which is to expand the market position of a given enterprise. The purpose of a particular enterprise is to obtain and shape proper resources of a human capital. Skilful use of human resources allows companies to work out a permanent competitive advantage on the market.

\section{References}

Beyer, K. (2010). Kapitał intelektualny jako zasób przedsiębiorstwa - koncepcje i modele zarządzania. Zeszyty Naukowe Uniwersytetu Szczecińskiego. Studia i Prace Wydziału Nauk Ekonomicznych i Zarządzania, (17 Przedsiębiorstwa w procesie zmian), 171-182.

Chomiak-Orsa, I. (2013). Zarzadzanie kapitałem relacyjnym $w$ procesie wirtualizacji organizacji. Podejście modelowe. Wrocław: Wydawnictwo Uniwersytetu Ekonomicznego we Wrocławiu.

Danielak, W. (2012). Wykorzystywanie kapitatu ludzkiego, strukturalnego i relacyjnego w budowaniu wartościowych relacji z interesariuszami przedsiębiorstwa. Zielona Góra: Wydawnictwo Uniwersytetu Zielonogórskiego.

Fitz-Enz, J (2000). The Role of Human Capital. New York: AMACOM.

Fitz-Enz, J. (2001). Rentowność inwestycji w kapitał ludzki. Kraków: Oficyna Ekonomiczna.

Ford, H. (2006). Moje życie i dzieło. Osielsko: Instytut Praktycznej Edukacji.

Grudzewski, W.M., Hejduk, I.K., Sankowska, A., \& Wańtuchowicz, M. (2009). Zarzadzanie zaufaniem w przedsiębiorstwie. Koncepcje, narzędzia, zastosowania. Kraków: Wolters Kluwer.

Jabłoński, M. (2002). Rola, struktura i pomiar kapitału intelektualnego organizacji. Ekonomika i Organizacja Przedsiębiorstwa, (11), 13-21.

Król, H., \& Ludwiczyński, A. (2006). Zarządzanie zasobami ludzkimi. Tworzenie kapitału ludzkiego organizacji. Warszawa: Wydawnictwo Naukowe PWN.

Mączyńska, E. (2011). Gdy sługa staje się panem, czyli dysfunkcje pomiaru wartości biznesu i wyników działalności gospodarczej. Zeszyty Naukowe Uniwersytetu Szczecińskiego (639/37, Finanse, Rynki finansowe, Ubezpieczenia), 1-15.

Mikuła, B., Pietruszka-Ortyl, A., \& Potocki, A. (2002). Zarzadzanie przedsiębiorstwem XXI wieku. Warszawa: Difin.

Nogalski, B., \& Rybicki, J. (ed.) (2007). Kształtowanie konkurencyjności małych $i$ średnich przedsiębiorstw. Gdańsk: Fundacja Rozwoju Uniwersytetu Gdańskiego.

Olesiuk, A. (2009). Inwestowanie w kapitał ludzki w Polsce. Szczecin: ECONOMICUS.

Piotrowski, Z. (2009). Kapitał ludzki w sektorze mikroprzedsiębiorstw w regionie łomżyńskim. Łomża: Wydawnictwo Wyższej Szkoły Zarządzania i Przedsiębiorczości im. Bogdana Jańskiego w Łomży.

Pocztowski, A. (2003). Kapitał intelektualny a zarządzanie zasobami ludzkimi. Zeszyty Naukowe Akademii Ekonomicznej w Krakowie, (629), 5-23.

Ritter, T., \& Walter, A. (2008). Functions, trust, and value in business relationships. Advances in Business Marketing and Purchasing, 14, 129-146. 
Rosińska, M. (2007). Kapitał ludzki podstawą budowania przewagi konkurencyjnej współczesnych przedsiębiorstw. In J. Bogdanienko, M. Kuzel, I. Sobczak (eds.), Uwarunkowania budowania konkurencyjności przedsiębiorstw w otoczeniu globalnym. Toruń: Wydawnictwo Adam Marszałek, pp. 11-20.

Rutka, R., Czerska, M., \& Kunc, L. (2009). Koncepcja wykorzystania pracowników w wieku przedemerytalnym $w$ procesie dzielenia się wiedza $w$ małych $i$ średnich przedsiębiorstwach. Wrocław: Wydawnictwo Uniwersytetu Ekonomicznego we Wrocławiu.

Skalik, J. (2006). Problem dynamiki zmian w zarządzaniu współczesnymi organizacjami. Prace Naukowe Akademii Ekonomicznej we Wrocławiu, (1141 Zmiana warunkiem sukcesu: dynamika zmian w organizacji - ewolucja czy rewolucja), 42-47.

Sveiby, K-E. (1998). The Invisible Balance Sheet: Key Indicators for Accounting, Control and Valuation of Know-how Companies. Stockholm: Affarsvarlden/Ledarskap.

Urbanowska-Sojkin, E., Banaszyk, P., \& Witczak, H. (2007). Zarządzanie strategiczne przedsiębiorstwem. Warszawa: PWE.

\section{Notes about the Authors}

Agnieszka Rzepka, Ph.D. - a researcher, works at Lublin University of Technology, Faculty of Management. She specializes in globalization, inter-organizational relationships, passionate of international research - recently carried out in Georgia. Certified business coach, participant of programs funded by the EU. Participant of national and foreign conferences (Harvard University, London School Economics and Political Science, Al. Ain University). She is an author of 3 monographs, more than 10 chapters, 70 articles published in domestic and foreign journals. Her recent study includes an article entitled Inter-organizational networks of cooperation based on the example of Poland, Canada and Georgia (2016).

BogusLaw ŚLuSARCZYK - University of Rzeszów Professor, Head of the Department of Macroeconomics and International Relations. His research interests focused on: quality, mismanagement and competitiveness. Participant of many grants and research projects. Member of many committees. He is an author of more than: 10 monographs, 70 articles published in domestic and foreign magazines and 30 chapters in publications. 